\title{
Corporate Social Responsibility: A Study of Selected Public Sector Banks in India
}

\author{
Sarita Moharana
}

\begin{abstract}
Corporate Social Responsibility is the mechanism through which the corporate organizations have executed their philanthropic visions for social welfare. It is a powerful way of making sustainable competitive profit and achieving lasting values for stakeholder as well as shareholder. "Corporate Social Responsibility is very popular in financial sector, which the financial crisis did not damage as perceptible as in other countries of developed economies (Singer, 2009)". The process of Globalization creates competition among financial organizations to perform according to the internationally compatible trade practices. So this instigated them to divert their available resources to do more social activities. Nowadays, many nationalized banks in India have created their individual brand image in the field of Corporate Social Responsibility (CSR) by taking various social initiatives in the era of social welfare and community development. The catalytic contributions made by nationalized banks for economic growth in India have created their separate entities towards financial growth. The main objective of this study is to analyze the CSR activities carried out by selected nationalized banks of India. An attempt has been made to analyze the existing CSR practices of five nationalized banks i.e., Allahabad Bank, Andhra Bank, Bank of Baroda, State Bank of India, and Uco Bank. It has been found that the selected banks are directly engaged in CSR activities mostly in the area of Rural Development, Education, Community Welfare, Women and Children. The analysis shows that, these banks are making efforts for the implementation of CSR, but are restricted within certain fields. There is a need for better CSR activities by the banks, which is possible by adding more and more social development issues link with corporate sector.

Keywords: Banking Sector, Corporate Social Responsibility, Financial Institution, Public Sector Banks,
\end{abstract}

\section{Introduction:}

The beginning of $21^{\text {st }}$ century in India has seen the term CSR coming to the forefront of development of discussion. In recent times, the Corporate Social Responsibility is emerging as a significant feature of business philosophy, reflecting the impact of business on society in the context of sustainable development. The emerging perspective on corporate social responsibility focuses on responsibility towards all stakeholders: shareholders, employees, creditors, suppliers, government, and community rather than only on maximization of profit for shareholders.CSR not only includes corporate regulatory compliance, but also refers to the act of making business successful through balanced, voluntary approaches to environmental and social issues in a way that is helpful to the society. The present day's economic growth and development in India mostly depends upon a well-knit financial system which comprises a set of sub systems of financial institutions, financial market financial instruments. Both financial markets and financial institutions play a crucial role in the financial system by rendering various financial services to the Indian community. CSR has been assuming greater importance in the corporate world, including the banking sector.

To highlight the role of banks in corporate social responsibility the RBI circulated a notice on December 20, 2007 for all the scheduled commercial banks, with title "Corporate Social Responsibility, Sustainable Development and Non-Financial Reporting-Role of Banks". Regarding the banking sector Bhatt (2008) stated that banks do not exist in a vacuum. They make a large contribution to the country's GDP growth , meet the demand of the growing middle class, contribute to infrastructure spending and reach out to the semi urban and rural areas .The Reserve Bank of India (RBI)2011on stressing the need for CSR, suggested the banks to pay special attention towards integration of social and environmental concerns in their business operations to achieve sustainable development .RBI also pointed out to start non-financial reporting (NFR) by the banks which will cover the work done by the banks towards the social, economic and environmental betterment of society.

\section{Purpose of the study:}

The purpose of the study is to highlight the existing CSR activities by selected banks and give suggestions for better CSR activities. The main objectives of this paper include:

- $\quad$ To study the existing CSR practices in selected Nationalized Banks.

- $\quad$ To suggest for the implementations of model CSR practices in Indian Banks. 


\section{Research Methodology:}

The present study covers five nationalized banks of India (Allahabad Bank, Andhra Bank, Bank of Baroda, State Bank of India, UCO Bank).Data are mainly collected both from primary and secondary sources. Primary data were collected on personal interaction with HR executives who are dealing with CSR activities in the respective banks. The secondary data has been collected from different sources like scholarly articles, annual reports of the selected banks, newsletters, and various web sites.

\section{COROPRATE SOCIAL RESPONSIBILITY}

The concept of Corporate Social Responsibility is not a new one but its focal point changes with the changing requirements of business and varying social needs. The concept of CSR was first mentioned in 1953 in the publication of "Social responsibilities of businessman" by William J.Bowen. However the term CSR became only popular in the 1990s. When the German Beta pharma generic pharmaceutical company decided to implement CSR.

CSR is a concept whereby companies decide voluntarily to contribute to a better society and a cleaner environment. It is represented by the contributions undertaken by companies to society through its business activities and its social investment. CSR has been making an increasingly prominent impact in the Indian social system by supplementing development projects. But it is not a novel concept in India as its historical roots goes till the Vedic age.

Today Banking Sector growing larger and powerful than before. Various Non-government organizations put pressure on Banks to act responsibly towards their stakeholders. Thus pressure has given rise to the concept named Corporate Social Responsibility. CSR defined as "the economic, legal, ethical, and philanthropic expectations placed on organizations by society at a given point in time." (Carrol and Buchholtz, 2000:35). Exactly what responsibility companies have towards society has been discussed for some decades now. A fundamental model which could be argued to reflect the outcome of this discussion is Carroll's (1991) four-part model in figure -1 .

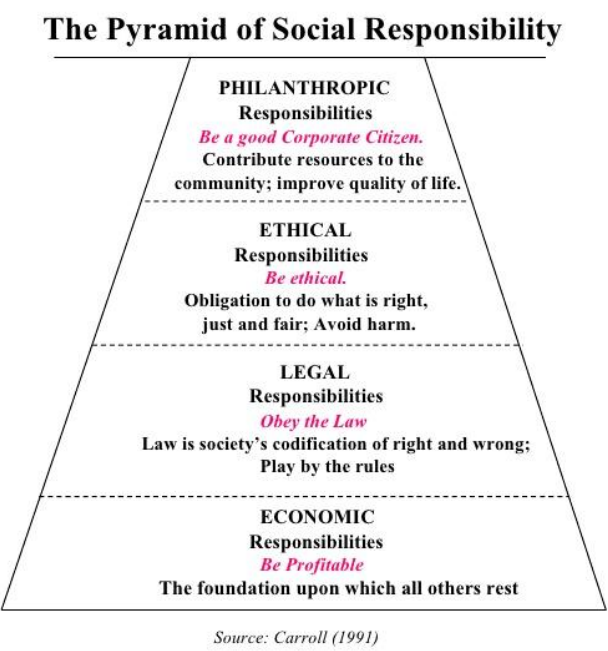

(Carroll's four-part model of corporate social responsibility (Carroll, 1991)

Economic responsibilities: The first responsibility of the company towards society refers to running the business as an economically healthy unit. It includes aspects such as return on investment for shareholders, fair employee salaries, and quality products supplied to customers at fair prices; all required by the society. (Crane \&Matten, 2004)

Legal responsibilities: Demands that companies act in accordance with existing legislation and regulatory requirements. The legal framework consequentially fosters society's ethical view and all companies attempting to be socially responsible are therefore required by society to follow the law. (Crane \&Matten, 2004)

Ethical responsibilities: It refers to corporation's responsibilities which are not covered by legal or economical requirements, but instead by what could be considered as 'right' or 'fair' in the eyes of society. Society therefore expects corporations to act ethically towards their stakeholders. (Crane \& Matten, 2004)

Philanthropic responsibilities: This involves corporation's willingness to enhance the quality of living for their stakeholders (i.e. employees, local community, and society at large) through charitable donations and organizational support. These corporate decisions are entirely voluntary, of less importance than the former three, and (with regards to social responsibility) only seen as desired by society. (Crane \& Matten, 2004). 


\section{Review of Literature:}

This section provides a review of the theoretical literature on CSR activities in Indian banking sectors. Howard Bowen in 1953 argued that since social institutions shaped economic outcomes it was to be expected that business firms as an economic outcome of societal interests should consider the social impact of business activity. According to Bowen, "CSR refers to the obligations of businessmen to pursue those policies to make those decisions or to follow those lines of relations which are desirable in terms of the objectives and values of our society." The choice of engaging in CSR activities by a firm depends upon the economic perspectives of the firm. There are firms which believe in maximizing shareholder value while there are firms which believe in maximizing profits. Milton Friedman (1962, p. 133) rightfully quotes: "Few trends would so thoroughly undermine the very foundations of our free society as the acceptance by corporate officials of a social responsibility other than to make as much money for their shareholders as they possibly can". CSR may be define as the notion that corporations have an obligation to constituent groups in society other than stockholders and beyond that prescribed by law or union contract, indicating that a stake may go beyond mere ownership (Jones, 1980). Corporate Social Responsibility (CSR) and orientation of banks can be a useful tool for them to tide over such crises in future, if banks maintain their relationships with stakeholders in making their businesses more sustainability .CSR among other things is a key stakeholder relationship building activity (Waddock and Smith, 2000).

Corporate social responsibility (CSR) is about the core behavior of companies and the responsibility for their total impact on the societies in which they operate. CSR is not an optional add-on nor is it an act of philanthropy. A socially responsible corporation is one that runs a profitable business that takes into account of all the positive and negative environmental, social and economic effects which has its impact on society (Marsden, 2001). The choice of engaging in CSR activities by a firm depends upon the economic perspectives of the firm. There are firms which believe in maximize shareholders value, while there are firms which believe in maximizing profits. Milton Friedman (1962, p. 133) rightfully quotes "Few trends would so thoroughly undermine the very foundations of our free society as the acceptance by corporate officials of a social responsibility other than to make as much money for their shareholders as they possibly can'. Recently the CSR has gained much attention in the corporate world.

Venu Srinivasan (2007) highlighted that Corporate Social Responsibility is more than philanthropy and must not mean "giving and receiving". An effective CSR initiative must engage the less privileged on a partnership basis. "CSR means sustainable development of the community by being partners in their progress. The government has been evolving a large number of welfare schemes for the people but experience shows that in most cases the benefits do not reach the most deserving. Industries have expertise in man management, financial management and business planning. They can easily provide the missing ingredients of leadership and organization and establish the "last mile connectivity" to reach the benefits to the deserving people. Therefore the focus of CSR could be „unlockinge the last mile connectivity. Industry must be a catalyst for social development. They must provide the leadership, know-how, training, etc. Jorge A. Arevalo and Deepa Aravind (2011) concluded in their article "Corporate Social Responsibility Practices in India: Approach, Drivers, and Barriers" that the CSR approach that is most favored by Indian firms is the stakeholder approach and that the caring or the moral motive, followed by the strategic or profit motive, are important drivers for Indian firms to pursue CSR. Further, the results indicate that the most significant obstacles to CSR implementation are those related to lack of resources, followed by those related to the complexity and difficulty of implementing CSR. As explained by Hertz (2012), earlier it was a form of capitalism that put much more emphasis on what we owned, on whether we had a Gucci handbag for example, than on things like the quality of our environment, the quality of the air we breathe, the kind of healthcare we have, what makes us content and happy. She called it Gucci capitalism and predicted that the gradual demise of Gucci capitalism will be followed by a new era of responsible capitalism called Co-opt capitalism. The idea of Co-opt capitalism is that the community matters over individual and co-operation matters over competition

\section{Role of Indian banking sector:}

Banking in India in modern sense has originated in the last decades of the 18th century. In the year 1969 there was a revolution in Indian Banking Sector. 14 private banks were nationalized in 1969 on 19th July by the then Central Government head by Prime Minister Smt. Indira Gandhi. In 1955, State Bank of India was nationalized. The main Moto of nationalization was to provide better quality service to the customers. Again in the year 1980 another 7 private banks were nationalized. The need for the nationalization was felt mainly because private commercial banks were not fulfilling the social and developmental goals of banking which are so essential for any industrializing country. Mainly the Indian Banking sector is made up 2 types of Banks. One is commercial banks another is cooperatives banks. Commercial banks include PSUs Banks, Private sector Banks, Foreign Banks, and Regional Rural Banks. Cooperatives Banks include urban cooperatives and State 
cooperatives Banks. The main aim of banks is to profit maximization but now a day's situation has been changed. The aim changed from profit maximization to do more and more CSR activities.

National Bank Financial Group is deeply engaged in creating the greatest possible value not only for investors, but also for its employees, clients and the communities where it is present. In this sense, CSR is a fundamental value. In all our sectors of activity-and whatever the business context-we work to integrate the social dimension, ethics and the environment with economic considerations so that we can continue to be a powerful engine of social and economic development. Among the measures which are employed, allow us to fulfill our responsibilities with respect to the community, are rigorous fundraising, donation and sponsorship programs organized by strongly committed teams of volunteer employees and retirees. Over the past few years, the concept of CSR has been changing. There has been an apparent transition from giving as an obligation or charity to giving as a strategy or responsibility. Like private banks, nationalized banks are not profit oriented. They gave more emphasis on CSR rather making profit.

\section{CSR practices in Indian Banking Sector:}

Now-a-days CSR has been assuming greater importance in the corporate world including financial institutions and banking sector. Banks and other financial institutions start promoting environment friendly and socially responsible lending and investment practices. RBI (2007) has also directed Indian banks to undertake CSR initiatives for sustainable development and also asked banks to begin non-financial reporting which is related to activities in the era of environmental, social and economic accounting.

It has been observed from karmayog's CSR ratings that most of the Indian public sector banks do not mention recent CSR activities on their annual reports or on the websites. The financial institutions do not take adequate steps for updating the recent activities in CSR .CSR has been assuming greater importance in the corporate world, including the banking sector. To highlight the role of banks in CSR, the RBI circulated a notice on December 20, 2007 for all the scheduled commercial banks in India.

Recently financial institutions adopt an integrated approach between customer satisfaction and CSR in a broader way. RBI also instructs the banks to integrate their business operation along with social and environmental aspects. The major key areas of CSR like, children welfare, community welfare, education, environment, healthcare, poverty eradication, rural development, vocational training, women empowerment, protection to girl child, and employment have been discussed in figure -2 .

\section{Figure: 2}

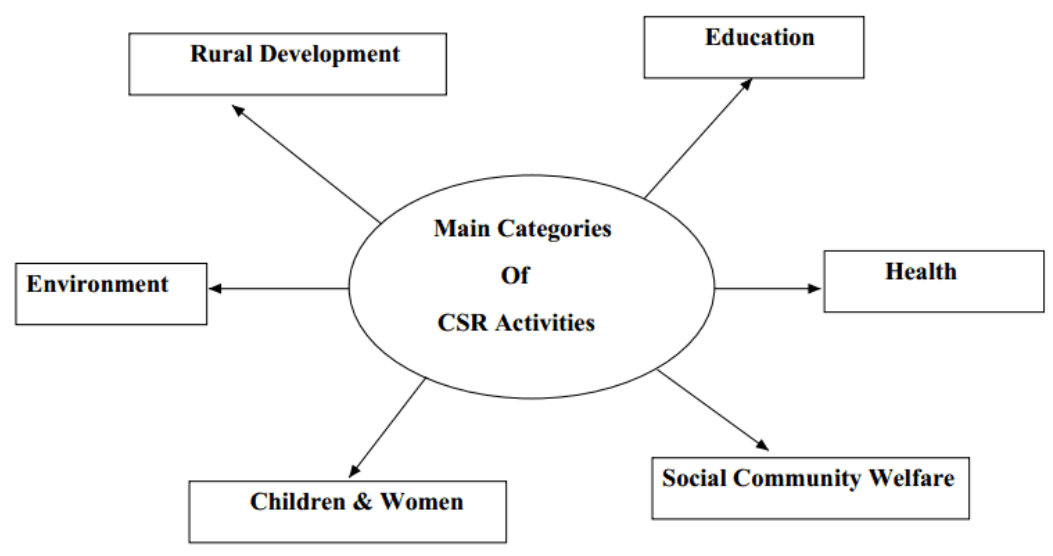

Education: All the five nationalized banks give major contributions towards education as education plays a very important role in everybody's life.SBI as a leading public sector bank plays a very key role in the field of education. It helps the needy people by providing education loan in the field of education. SBI Education Loans has grown by 9.43\% during FY 2012-13. It has a total exposure of Rs. 13,751 cores as on Mar 2013.SBI Loan Scheme for Vocational Education and Training was launched in July 2012 and loans up to Rs. 1 lakh are given under this scheme. Maximum Loan Amount for Studies Abroad has also been increased to Rs. 30 lakh from the previous limit of Rs. 20 lac. Same as UCO Bank: An amount of Rs. 4.90 lakh to Shivaji University, Kolhapur, 
Maharashtra under environment protection category for installation of Solar Plant Device. Rs. 2 lakh to Ramakrishna Math, Nattarampalli, Vellore, Tamilnadu for construction of building for an orphanage. Rs. 10 lakh to Mahaveer Viklang Sahayata Samity, Jaipur for helping the physically challenged. To facilitate education \& women empowerment a sum of Rs. 10 lakh was donated to Ramakrishna Mission Sister Nivedita Girls" School. Rs. 6 lakh to Rajiv Gandhi Foundation, New Delhi for purchasing vehicles with disabled-friendly attachment. Bank of Baroda has been giving donations for the following purposes for the spread of education including for the girl child and womenfolk in remote villages. To reputed colleges/public schools and other similar institutions. Like wise Andhra bank is setting up a school in the campus of Andhra University in Vishakhapatnam. Along with the Andhra Pradesh Government and NABARD, it has set up APBIRED for providing training to unemployed youth for improving their skills. In the year 2007-2008, the bank has donated $2.14 \mathrm{cr}$ to various trusts and NGOs. Allahabad Bank has launched a scheme to meet the total financial requirement of self help groups (SHGs) members for taking up economic activities and meeting social needs such as Housing, Health, Marriage, Educations and Consumption and Swapping of debts to informal lenders. Total financial assistance under the scheme is to the extent of Rs. 50,000/- per member of SHG with a maximum ceiling of Rs. 5.00 lakhs per SHG.

Enviournment: All most all the five banks have taken major steps or programs for enviournmental protection. State Bank of India has a comprehensive CSR policy approved by the Board and the focus areas are Supporting Education, Entrepreneur development \& Health care, Assistance to Poor and under privileged, Environmental protection, clean energy, and help in National calamities. SBI is always in forefront to help states affected by natural calamities. During the current fiscal SBI has lent its helping hand to the States of Assam, Sikkim, Uttarkhand, Maharashtra etc with donation to Chief Minister's Relief fund to respective States provide to the people affected by flood to a tune of Rs.9.00 core. In spite of these the bank is also engaged in tree planting activities. Likewise UCO bank A new scheme named UCO Estate Purchase Loan was launched based on the guidelines received from Department of Financial services, Ministry of Finance, Government of India to extend financial assistance for purchase of Estates growing traditional crops like coffee, tea, rubber, cardamom, cashew nut, pepper, coconut and other perennial crops. An amount of Rs. 4.90 lakh to Shivaji University, Kolhapur, Maharashtra under environment protection category for installation of Solar Plant Device. Bank of Baroda formulated various area-specific schemes tailor-made to the needs of local requirements, particularly where there is a concentration of industries like Rice Mills, Cold storages, Poultry units, etc. The suitable concessions in rate of interest, charges were allowed under these schemes to garner maximum business out smarting competition. As many as 18 area-specific schemes were formulated to increase the agricultural lending and also the bank made donation in the field of Adoption of gardens in cities where the Bank's name can be publicized. Allahabad Bank identified the thrust areas such as financing of supply chains for Agri Business development, Plantation \& Horticulture, Minor Irrigation development, Post harvest storage infrastructures, lending to SHGs/JLGs through Micro Finance Institutions etc to accelerate credit flow to priority sector with special emphasis to Agriculture sub- sector during 2008-09. As a part of its CSR activities, the Bank has initiated adoption of wild animals at 'Van Vihar' Bhopal showing its love for wild animals. The Bank has adopted following animals for one year commencing from1stApril, 2010Tigress 'BASANI', Leopard' AGNI', SlothBear 'KAMAL' Andhra Bank is not taking any initiatives in field of environment.

Health: Health plays a vital role in everybody's life. All the public sector banks have taken various initiatives, various programs in the field of health. State Bank of India for the financial year 2012-13, earmarked Rs.117.07 crore i.e. $1 \%$ of SBI's previous year profit for CSR activity. During the current financial year, the Bank has extended financial assistance for 300 Ambulance Vans to needy and service organizations, 42,000 water purifiers and 1, 40,000 ceiling fans to more than fifty thousand schools to provide clean water and conducive climate to school children. Under health care activities SBI has extended assistance to a tune of Rs. 14 crores for support to hospitals in the form of Medical equipments and others. UCO bank under health care category Thalassaemia Society of India was provided with Bank's donation of Rs. 6 lakh for treatment of Thalassaemic children belonging to BPL category. A van costing Rs. 7.90 lakh was donated to Disha Foundation, Jaipur for the physically and mentally retarded. Bank of Baroda Vaccination projects for controlling spread of diseases/epidemics Providing support to organizations extending support to handicapped persons like blind, lame, deaf and dumb, etc or suffering from any other disabilities During the Financial Year FY13, the Bank disbursed donations amounting to Rs.699.74 lakh to various organizations engaged in the field of education, health, women welfare etc. In Allahabad bank Corporate Social Responsibility (CSR) was introduced for the first time in the Bank in September / October, 2012. The bank give financial support to Provision of arsenic-free drinking water in a village, Contribution towards development of the interior of a high quality diagnostic clinic meant for the economically weaker sections of the society; Contribution towards renovation of a rehabilitation centre for mentally challenged women, Donation of a vehicle to Centralized Accident \& Trauma Services 
(CATS) to be used for field inspection. Andhra Bank Being an integral part of society bank is aware of its corporate social responsibilities and has engaged in community and social investments During the year '07-'08 the bank has adopted Gundugolanu village in Andhra Pradesh for improving health, sanitation, education facilities with a comprehensive budget of $5.50 \mathrm{cr}$.

Rural Development: All the public sector banks are having highest number of rural branches in India. So all the banks take steps for development of rural people. The State Bank of India (SBI) is committed to spending one per cent of its profits in social welfare activities for the benefit of the community. Accordingly, while the bank's profit last year was Rs. 8,200 crore, it spent Rs. 82 crore in community welfare activities under its corporate social responsibility, according to its Deputy Managing Director Sharad Sharma. RBI said to every bank that they should spent $1 \%$ of the net profit on CSR activities. UCO Bank has received the "Second Position for National Award" for Excellence in Micro Enterprises Lending during 2007-08. The Bank's Chairman \& Managing Director received the Award from Shri Manmohan Singh, the Hon'ble Prime Minister of India on 30.08.2008.The Bank also received the "BEST BANK" National Award for lending under Rural Employment Generation Programme in Eastern Zone from the Chairperson of Khadi Village \& Industries Commission. The Bank has launched several new Schemes during the year 2012-13, UCO KISAN BHOOMI VRIDHI Scheme, UCO KISAN TATKAL Scheme, UCO ESTATE PURCHASE LOAN Scheme, Scheme for Solar Irrigation Pump set, UCO KISAN ALL PURPOSE TERM LOAN SCHEME, Scheme for relending to individual borrowers having settled their Direct Agriculture loan dues under Compromise/ One time settlement scheme (OTS)/legal action. Bank of Baroda has always believed in making a difference to society at large. As a responsible corporate citizen, it has been its vision to empower the community through socio-economic development of underprivileged and weaker sections. Most of the Bank's social activities are linked to rural masses, i.e., adoption of 101 villages across India for their all-around development and providing financial assistance for development of infrastructure facilities like setting up village libraries, community hall and solar lighting systems in villages. The Bank had adopted 500 villages for 100\% Financial Inclusion, and this has already been achieved in all 500 villages. The Bank formulated various area-specific schemes tailor-made to the needs of local requirements, particularly where there is a concentration of industries like Rice Mills, Cold storages, Poultry units, etc. Allahabad Bank: The Bank, as a responsible corporate citizen, has initiated the following measures towards sustainable development of the society reflecting its concern for human rights and environment. The Bank has established two more Rural Self Employment Training Institutes (RSETI) this year for imparting training to Farmers, unemployed youths, NGOs, SHGs etc. for improvement of skills and entrepreneurship ability. . The Bank had extended financial support in different sectors like Provision of arsenicfree drinking water in a village. Andhra Bank: Being an integral part of society bank is aware of its corporate social responsibilities and has engaged in community and social investments. Bank has taken many initiatives with the objective of providing philanthropic assistance for development, education etc. The Bank has taken initiatives for including more people from the marginalized and down trodden sections into the banking system.Under the aegis Andhra bank rural development trust bank is imparting training to youth in rural and semi urban areas so that poor people can take up self employment ventures. The bank has already implemented financial inclusions in districts of Orissa and Andhra Pradesh. During the year '07-'08 the bank has adopted Gundugolanu village in Andhra Pradesh for improving health, sanitation, education facilities with a comprehensive budget of $5.50 \mathrm{cr}$.

Children \& Women: State Bank of India has constituted SBI's Children's Welfare scheme as a trust in 1983.The corpus of the fund is made up of contribution by staff members with equal contribution by the Bank. The Bank extends grants from this fund to institutions engaged in the welfare of under privileged / downtrodden children like orphans; destitute, challenged and deprived etc.CSR is not an isolated practice or initiative for SBI but runs through its entire business paradigm. In SBI there is a department name Community Service Banking which deals with CSR activities. Mainly SBI deals with Donations, Adoption of girl child, blood donation camps, Medical camps, Family Planning Camps, Veterinary Camps, Adult literary classes, Ladies club activities, Tree planting Activities special programme for children and other cultural activities. UCO Bank Women beneficiaries were given finance to the tune of Rs. 3429 crore which constitutes 6.89 per cent of Adjusted Net Bank Credit against the National Parameter of 5 per cent. As on 31.03.2009, credit facilities of Rs. 3176 crore has been extended to Minority Communities which is 13.01 per cent of Priority Sector Advance as against the target of 13 per cent set for the year. Under health care category Thalassaemia Society of India was provided with Bank's donation of Rs. 6 lakh for treatment of Thalassaemic children belonging to BPL category. A van costing Rs. 7.90 lakh was donated to Disha Foundation, Jaipur for the physically and mentally retarded. Rs. 5.00 lakhs as donation was awarded to Kharda Janakalyan Rognirnoy Kendra, Kharda for running a diagnostic clinic for the weaker sections. Bank of Baroda During the Financial Year FY13, your Bank disbursed donations amounting to Rs.699.74 lakh to various organizations engaged in the field of education, 
health, women welfare etc. The Bank coordinates its CSR activities with its Micro-finance and Self-Help Group (SHG) financing. The Bank has developed relationships with 91,536 SHG and has extended credit facilities of Rs 636.00 crore through SHGs, whereby million of households have been beneficiaries of financial inclusion. Allahabad Bank Corporate Social Responsibility (CSR) was introduced for the first time in the Bank in September / October, 2012 and was targeted mainly on the rural populace. The Bank had extended financial support in different sectors as below .Provision of arsenic-free drinking water in a village. One time support to 10 tribal girl children for their education. Contribution towards renovation of a rehabilitation centre for mentally challenged women. Andhra Bank has taken initiatives for including more people from the marginalized and down trodden sections into the banking system. Under the aegis Andhra bank rural development trust bank is imparting training to youth in rural and semi urban areas so that poor people can take up self employment ventures. They also conduct vocational and human resource development training. So far they have provided training to 71,666 participants. The bank has taken initiatives for including more people from the marginalized and down trodden sections into the banking system.

Social Community Welfare: As per the data highest number of banks has contributed for social community welfare activity. State Bank of India is always in forefront to help states affected by natural calamities. During the current fiscal SBI has lent its helping hand to the States of Assam, Sikkim, Uttarkhand, Maharashtra etc. with donation to Chief Minister's Relief fund to respective States provide to the people affected by flood to a tune of Rs.9.00 crore. UCO Bank Overlay the CSR activities of the bank are lending to agriculture, financing new farmers, issuance of kissan credit card, finance to women beneficiaries, finance to minority community, finance to weaker section of society, advances under education loan scheme, financing of micro, small and medium, enterprises. Bank has formed a trust "UCO DEVELOPMENT TRUST" through which the bank has started entrepreneurship development center at Howrah (Westbengal) and Puri (Orissa). The Bank believes that carrying out Corporate Social Responsibility (CSR) helps in tangible value-creation. Moreover, CSR creates a positive image in the society and inculcates essence of loyalty for the Bank among a cross-section of countrymen. In tune with this perception, the Bank made separate donations for deserving as well as noble causes during the year Rs. 10 lakh was extended to Chief Minister's Relief Fund, Sikkim for assistance during natural calamity. Bank of Baroda has been giving donations for the following purposes: For the spread of education - including for the girl child and womenfolk in remote villages. To reputed colleges/public schools and other similar institutions. To reputed hospitals engaged in charity or in service of weaker sections Assisting families of soldiers died in wars and handicapped soldiers, Old age homes, Preservation of places of historical interest like gardens, forts, temples etc. Promotion of efforts for protection, conservation and cleaning of environment including plantation/re-plantation, rivers, lakes, forests, sanctuaries etc, Adoption of gardens in cities where the Bank's name can be publicized ,Family planning activities, , For promoting the promotion and use of non exhaustible sources of energy like solar power, gobar gas plants in rural areas, Vaccination projects for controlling spread of diseases/ epidemics,Providing support to organizations extending support to handicapped persons like blind, lame, deaf and dumb, etc. Allahabad Bank has launched a scheme to meet the total financial requirement of self help groups (SHGs) members for taking up economic activities and meeting social needs such as Housing, Health, Marriage, Educations and Consumption and Swapping of debts to informal lenders. Total financial assistance under the scheme is to the extent of Rs. 50,000/- per member of SHG with a maximum ceiling of Rs. 5.00 lakhs per SHG. Andhra Bank Being an integral part of society bank is aware of its corporate social responsibilities and has engaged in community and social investments. Bank has taken many initiatives with the objective of providing philanthropic assistance for development, education etc.Under the aegis Andhra bank rural development trust bank is imparting training to youth in rural and semi urban areas so that poor people can take up self employment ventures.

\section{CSR Activities in Five Major Banks}

\begin{tabular}{|c|c|c|c|}
\hline Name of the Bank & CSR areas & 3 main CSR activities & $\begin{array}{l}\text { CSR budget } \\
\underline{2009-10}\end{array}$ \\
\hline State bank of India & $\begin{array}{l}\text { Community service banking } \\
\text { Disaster Relief } \\
\text { Children } \\
\text { Education } \\
\text { Energy } \\
\text { Enviournment } \\
\text { Physically challenged } \\
\text { Poverty Eradication } \\
\text { Vocational Training } \\
\text { Women } \\
\text { Rural community- } \\
\text { Development. } \\
\end{array}$ & $\begin{array}{l}\text { Education } \\
\text { Girl Child } \\
\text { Poverty Eradication }\end{array}$ & 19.72 crore \\
\hline
\end{tabular}




\begin{tabular}{|c|c|c|c|}
\hline & $\begin{array}{l}\text { Adoption of girl child } \\
\text { Research and development- } \\
\text { On education. }\end{array}$ & & \\
\hline UCO Bank & $\begin{array}{l}\text { Community welfare } \\
\text { Education } \\
\text { Rural Development } \\
\text { Vocational training } \\
\text { Women }\end{array}$ & $\begin{array}{l}\text { Rural Development } \\
\text { vocational training } \\
\text { Community welfare }\end{array}$ & Not disclosed \\
\hline Allahabad Bank & $\begin{array}{l}\text { Community Welfare } \\
\text { Education } \\
\text { Rural Development } \\
\text { Vocational Training } \\
\text { Women } \\
\text { Poverty Eradication } \\
\end{array}$ & $\begin{array}{l}\text { Farmer's Welfare } \\
\text { Vocational training } \\
\text { Finance to underserved }\end{array}$ & Not disclosed \\
\hline Bank of Baroda & $\begin{array}{l}\text { Community welfare } \\
\text { poverty eradication } \\
\text { physically challenged } \\
\text { rural Development } \\
\text { vocational training } \\
\text { women }\end{array}$ & $\begin{array}{l}\text { rural development } \\
\text { women's empowerment } \\
\text { vocational training }\end{array}$ & Not disclosed \\
\hline Andhra Bank & $\begin{array}{l}\text { Children } \\
\text { Social security pensions } \\
\text { Helping flood victims } \\
\text { Donating various social } \\
\text { organizations } \\
\text { Community welfare } \\
\text { education } \\
\text { rural development } \\
\text { Vocational training }\end{array}$ & $\begin{array}{l}\text { Vocational Training } \\
\text { Rural Development } \\
\text { Community welfare }\end{array}$ & 4.16 crore \\
\hline
\end{tabular}

\section{Conclusion:}

The perspective of Corporate Social Responsibility by initiating social and community initiatives is to benefit the society and nation at large which sought to be achieved through the participation of its employees. Though these five banking sectors have taken effect in the era of CSR but it is not satisfactory. In order to attain the social objectives there is a need to frame a CSR policy in every bank and prioritization of activities for social spending and allocation of separate funds should be given for this specific purpose. The banks also created maximum value from its activities and developed strategies to effectively communicate progress with various stakeholders and provide information on the issues that concern them. To have an impact of spending and utilization of allocated budget by CSR there should be a system of periodical monitoring and reporting to the Board of Directors. Most banks use CSR as a marketing tool to spread the word about their business, Generally speaking, most banks seem either unaware or don't monitor their CSR. Special training needs to be given to business managers in working with social issues and Participation of small and medium business should be encouraged... The concept of CSR has failed to some extent to take deep root in India because of lack of coordination between the banks, government, and non-government organizational efforts. The Financial Institutions should realize that running an efficient and profitable business organization means ensuring that the surrounding communities and environment grew and prospered along with the institutions. In a nutshell, it can be said that the state of mind of the Indian entrepreneurs towards CSR is changing due to tough competition in an international level. Conclusively, there are three suggestive measures which are advisable for a better CSR in these banks. First is to enhance and accelerate government's involvement in CSR activities, Second can be noted as development of a broad sector of the consulting in the era of CSR, and lastly media should increase its interest and play a vital role in the era of CSR.

\section{References:}

[1]. Agrawal, Sanjaoy K,” Corporate Social Responsibility in India “(2008) Response Business Book from Sage, Sage Publications, New Delhi.

[2]. Annual Report of Banking Institutions, 2007-2008,2008-2009 and2009-2010

[3]. Baxi, C V \& Prasad Ajit (Ed) (2005), Corporate Social Responsibility-Concept and Cases, New Delhi, Excell Books.

[4]. Bihari, Suresh Chandra and Pradhan ,Sudeepta(2011),CSR and performance :The story of Banks in India .Journal of Transational Management16(1),20-35

[5]. B lowfield, Michael \&Murray Alan (2008), corporate responsibility -a critical introduction, Great Clarendon street, Oxford University Press.

[6]. Chaudhury SK, DAS SK \& Sahoo PK ,"Practices of Corporate Social Responsibility (CSR) in Banking Sector in India: An Assessment", Research Journal of Economics Business and ICT:76-81 
[7]. Das Sanjay Kanti (2012),"CSR Practices and CSR Reporting in Indian Financial Sector", Jr. of International Journal of Business and Management Tomorrow, Vol.2 (9):1-12.

[8]. Griffin Ricky W.(Ed) (2002),Management, New Delhi ,A.I.T,B.S publishers

[9]. Karmayog Report(2010), Retrived from http://www.Karmayog.org/CSR 2010

[10]. Kavitha N.V ,Reddy N.Suma,"Corporate Social Responsibility in Indian banking Sector:"A Comparison of CSR initiatives in commercial and private banks" $329-349$

[11]. Mohan A, :( 2001) Corporate Citizenship: perspectives from India. Journal of corporate citizenship

[12]. Potluri RM,Ansari Rizwana,KhanSR,Challa SK (2012): Corporate Social Responsibility :An Outlook of Indian Financial Institutions",British Journal of Economics, Management and Trade2(4):296-308

[13]. Pradhan Sudeepta" :"CSR Inclusion In Firms: A study of Indian Banks"66-75

[14]. Sharma Eliza ,Dr.Mani Mukta Mani, "Corporate Social Responsibility: An Analysis of Indian Commercial Banks", AIMA journal of Management \& Research , February 2013,Volume7,Issue1/4,ISSN0974-497

[15]. Sharma Nishi, (2011),"CSR Practices and CSR Reporting in Indian Banking Sector”, Jr.of International Journal of Advanced Economics and Business Management, 1(2), 58-66.

[16]. Walter De Gruyter: (1985) Legal, Economics and Sociological analysis on Corporate Social Responsibility. 